\title{
The effects of zinc biofortification of seeds and NPK fertilizer application on the growth and yield of sesame (Sesamum indicum L.)
}

\author{
Ehiokhilen Kevin EIFEDIYI ${ }^{1,2}$, Grace Adejoke ILORI ${ }^{1}$, Henry Emeka AHAMEFULE ${ }^{1}$, Abduquadir Yusuf \\ IMAM $^{1}$
}

Received August 28, 2019; accepted Janjuary 28, 2021. Delo je prispelo 28. avgusta 2019, sprejeto 28. januarja 2021.

The effects of zinc biofortification of seeds and NPK fertilizer application on the growth and yield of sesame (Sesamum indicum L.)

Abstract: Soils of the southern Guinea savanna zone of Nigeria are inherently infertile due to shortened fallow period and the continuous use of inorganic fertilizer which depletes the soil of micronutrients such as zinc over time. A field trial was carried out at the Teaching and Research Farm of the University of Ilorin, Nigeria during the 2016 and 2017 cropping seasons to evaluate the effect of zinc and NPK fertilizer on the growth, yield and zinc concentration of seeds of sesame. The experiment was laid out as a factorial fitted into a randomized complete block design (RCBD), replicated thrice. The treatment consisted of four levels of $\mathrm{ZnSO}_{4}\left(0,5,10\right.$ and $\left.15 \mathrm{~kg} \mathrm{ha}^{-1}\right)$ and four levels of NPK 15:15:15 (0, 100, 200 and $\left.300 \mathrm{~kg} \mathrm{ha}^{-1}\right)$. Data collected were subjected to analysis of variance (ANOVA) and means were separated using new Duncan multiple range test at $5 \%$ level of probability. Results obtained showed significant effects of $\mathrm{Zn}$ and NPK rates on plant height, number of leaves, yield per plot and yield per hectare. The application of $15 \mathrm{~kg} \mathrm{ha}^{-1} \mathrm{Zn}$ and $300 \mathrm{~kg} \mathrm{ha}^{-1}$ (15:15:15) NPK resulted in high yield and high zinc content of seeds.

Key words: bio-fortification; sesame; growth; yield
Učinki biofortifikacije semen s cinkom in uporaba NPK gnojil na rast in pridelek sezama (Sesamum indicum L.)

Izvleček: Tla v južno gvinejski savanski coni Nigerije so nerodovitna zaradi prekratkih obdobij prahe in stalne uporabe mineralnih gnojil, kar s časom povzroča obubožanje tal na mikrohranilih kot je zink. Poljski poskus je bil izveden na učnem in raziskovalnem posestvu Univerze v Ilorinu, Nigerija, v rastnih sezonah 2016 in 2017 za ovrednotenje učinka cinka in NPK gnojil na rast in pridelek ter vsebnost cinka v semenih sezama. Poskus je bil faktorski, popolni bločni poskus (RCBD) $s$ tremi ponovitvami. Obravnavanja so obsegala štiri ravni cinka kot $\mathrm{ZnSO}_{4}\left(0,5,10\right.$ in $\left.15 \mathrm{~kg} \mathrm{ha}^{-1}\right)$ in štiri ravni NPK 15:15:15 $\left(0,100,200\right.$ in $\left.300 \mathrm{~kg} \mathrm{ha}^{-1}\right)$. Variabilnost zbranih podatkov je bila analizirana $\mathrm{z}$ ANOVA, poprečja so bila ločena $\mathrm{z}$ multiplim Duncanovim testom rangov pri $5 \%$ verjetnosti. Izsledki so pokazali značilne učinke $\mathrm{Zn}$ in NPK na višino rastlin, število listov, pridelek na ploskev in pridelek na hektar. Uporaba $15 \mathrm{~kg}$ $\mathrm{ha}^{-1} \mathrm{Zn}$ in $300 \mathrm{~kg} \mathrm{ha}^{-1}$ (15:15:15) NPK je dala največji pridelek in največjo vsebnost cinka v semenih.

Ključne biofortifikacija; sezam; rast; pridelek 


\section{INTRODUCTION}

Low input agriculture is no longer sustainable due to increasing population, thus the use of inorganic fertilizer for the improvement of growth and yield to prevent hunger and starvation has become imperative (Graham et al., 2001), hence, farmers in the Guinea savanna zone of Nigeria cultivate their crops intensively relying on nitrogenous and phosphate fertilizers to increase crop growth and yield. However, the continuous use of inorganic fertilizer can deplete the soil of valuable micronutrients and sometimes can cause zinc antagonism (Haas et al., 2016) and these valuable micro nutrients are vital for crop growth and human health. Subsequently, soils low in mineral composition produce seeds and vegetative parts with even lower mineral contents. Roughly one third of the world's population suffers from hidden hunger which results from deficiencies of vitamins (particularly A and C) and minerals (such as zinc, iodine and iron), which leads to illness that is more severe in children than adults (GNR, 2003; Kennedy et al., 2004). Zinc is involved in many enzymatic reactions in crops such as carbohydrate metabolism and protein synthesis and its shortfall results in discoloration of leaves, impaired growth and delayed sexual development in human (Haas et al., 2016; Vootman \& Bindraban, 2015; Haas et al., 2012). Cakmak (2008) reported that over thirty percent of the diet of the world's population is deficient in zinc. This is attributed to crop production in areas with low soil mineral availability and consumption of crops with inherently low mineral content, low fish intake and other animal products in their diet due to poverty (Graham et al., 2001). Majority of rural dwellers in the southern Guinea savannah zone of Nigeria depends on cereals as staple food, have no access to fruits, vegetables and cannot afford fish and animal products because of poverty. Black et al. (2013) had reported severe zinc deficiency in children under five years old in some parts of Africa including Nigeria due to low zinc in their soil. In addition, this low zinc concentration in soil solution is due to its limited mobility in the soil (Cakmak, 2014); hence difficulty in plant roots to absorb it for its growth, development and its availability in plant tissues. One of the ways of overcoming this pitfall is through biofortification using zinc.

Biofortification is a process of making essential nutrients bio-available to crops during crop growth using agronomic and genetic methods (Bouis et al., 2011). Several methods have been used for the biofortification of crops, namely; breeding and agronomic approach using inorganic fertilizer (Cakmak, 2008). Rice has been biofortified with zinc in Bangladesh using breeding method (Chowdhury, 2014) whereas Zou et al. (2012) reported an increase in the concentration of zinc by up to 20 parts per million in wheat seeds in India and Pakistan by foliar spray, but in maize and rice, foliar spray of zinc resulted in only a small effect (Phattarakul et al., 2012). Suresh et al. (2013) reported a significant improvement in growth and yield of sesame using $25 \mathrm{~kg} \mathrm{ha}^{-1} \mathrm{ZnSO}_{4}$ but no report of its concentration on the seeds. However, biofortified staple foods cannot provide high level of minerals and vitamin supplements compared to industrially fortified foods, but they can help by increasing the daily adequacy of micronutrient intake in humans (Bouis et al., 2011). The biofortification of local staples will help to bridge this micronutrients and vitamins gaps (Hotz \& McClafferty, 2007) thereby reducing disease prevalence among the rural populace. The soils of the Guinea savannah zone of Nigeria are deficient in zinc (Aduloju, 2000) and farmers hardly apply zinc fertilizer. Developing biofortified crops can improve the efficiency of growth in these soils with depleted or very low mineral composition (Borg et al., 2009). Cakmak (2008) reported the daily requirement of zinc for different age groups ( $10 \mathrm{mg}$ for children, $12 \mathrm{mg}$ for women and $15 \mathrm{mg}$ for men) whereas Pavlotska (2007) noted that nursing mothers require $25 \mathrm{mg}$ per day of zinc. The objective of this study was to determine the effect of zinc and NPK fertilizer on the growth and yield of sesame.

\section{MATERIALS AND METHODS}

\section{1 THE EXPERIMENTAL SITE}

Field experiment was conducted at the Teaching and Research Farm of the University of Ilorin, Ilorin, Nigeria during the 2016 and 2017 cropping seasons. The study area is situated in the southern Guinea savannah on (Latitude $04^{\circ} 35^{1} \mathrm{~N}$ and Longitude $08^{\circ} 29^{1} \mathrm{E}, 307 \mathrm{~m}$ above sea level). The average rainfall of the area is between 1000-1540 mm which is bimodal in occurrence.

\section{2 EXPERIMENTAL LAYOUT AND SOWING OF THE SEEDS}

The land was ploughed and harrowed before marking out into plots. The size of each plot was $3 \mathrm{~m} \times 3 \mathrm{~m}$ with a $0.50 \mathrm{~m}$ avenue between the plots. The seeds of sesame (Ex-Sudan cultivar) which were obtained from the National Cereal Research Institute of Nigeria, Badeggi, Niger State, Nigeria were sown on the $15^{\text {th }}$ of July, 2016 and repeated on July 15; 2017 using the drilling method at a depth of $2.5 \mathrm{~cm}$ and the seeds were covered lightly with soil to prevent desiccation by sunlight. The seed- 
lings were later thinned three weeks after sowing to two plants per stand at a spacing of $30 \times 30 \mathrm{~cm}$ between and within rows.

\section{3 EXPERIMENTAL DESIGN}

The experiment was laid out in a factorial arrangement fitted into a randomized complete block design (RCBD) replicated thrice. The factors were NPK $(15: 15: 15)$ fertilizer rates $\left(0,100,200,300 \mathrm{~kg} \mathrm{ha}^{-1}\right)$ and $\mathrm{ZnSO}_{4}$ levels $\left(0,5,10,15 \mathrm{~kg} \mathrm{ha}^{-1}\right)$. The NPK fertilizer was applied $10 \mathrm{~cm}$ away from the plant using the side band placement method while the zinc sulphate was applied mid-morning by foliar method using a knap sack sprayer at three weeks after sowing. Zinc is commonly applied to crops as $\mathrm{ZnSO}_{4}$ (Cakmak, 2008), as this will help to increase the micronutrient content in edible parts (Prasad et al., 2015).

\section{4 SOIL AND SEED ANALYSES}

Soil samples from the experimental plot were collected from the top soil at a depth of $0-30 \mathrm{~cm}$ from a $2.5 \times 2.5 \mathrm{~m}$ grid, bulked; then a composite was taken for physical and chemical analyses before and at the end of the cropping seasons. The soil samples collected were air dried ground and passed through a $2 \mathrm{~mm}$ sieve. The sieved soil samples were taken to the laboratory for chemical analysis, as described by Carter \& Gregorich (2007). Soil organic carbon was determined by the procedure of Walkley \& Black using the dichromate wet oxidation method (Nelson \& Sommers, 1996). Organic matter was estimated by multiplying carbon (C) by 1.724 . Total nitrogen was determined by Micro-Kjeldahl digestion and distillation techniques (Bremner, 1996), and available phosphorus was determined following Bray No 1 $\left(1 \mathrm{~N} \mathrm{NH}_{4} \mathrm{~F}+0.5 \mathrm{~N}\right)$ extractant by vanado-molybdo-phosphoric acid method (Kuo, 1996), Soil pH was measured (soil: water ratio, 1:2) using a glass electrode; particle-size analysis was done using the hydrometer method (Gee \& Or, 2002). Textural class was determined using a textural triangle (Brady \& Weil, 1999; Hunt \& Gilkes, 1992) and extraction of exchangeable bases was done by using IN ammonium acetate, exchangeable $\mathrm{K}$ and $\mathrm{Na}$ were determined by using flame photometry while calcium and magnesium were analyzed by atomic absorption spectrophotometry.

The total zinc concentrations in the seed samples were determined by wet digestion method as described by Minaleshewa et al. (2010) and concentrations in the extracts were determined by flame atomic absorption
Spectrometry while its concentration in the soil was determined by the method of (Maclean \& Langille, 1976).

\section{5 DATA COLLECTION AND ANALYSIS}

Data were collected on growth parameters (plant height, number of leaves, and leaf area index), dry matter accumulation, yield parameters (number of capsules per plant, length of capsule, yield per net plot and yield per hectare). The plant height was assessed by measuring the plant from the ground level to the terminal point using a measuring tape, while the number of leaves was assessed visually by counting the green leaves of the five tagged plants in the net plot (60 plants) whereas the leaf area was calculated based on the work of Silva et al. (2002) using:

$$
S=0.3552 \times C^{2}
$$

where $S=$ leaf area in $\mathrm{cm}^{2}$ and $C=$ leaf longitudinal length $\mathrm{x}$ breadth while the leaf area index was estimated as;

$$
\frac{\text { leaf area }}{\text { ground cover }}
$$

The data on yield components were collected on number of capsules per plant, length of capsule, seed mass per net plot and seed mass per hectare. Data on number of capsules per plant was estimated by counting, the length of capsule was calculated by the use of digital Vernier caliper, while the yield per net plot (60 plants) was carried out by weighing the seeds by using a sensitive balance whereas the yield per hectare was extrapolated from the yield per net plot and the data collected were subjected to general analysis of variance (ANOVA) using Genstat statistical software (17th edition). Treatment differences were compared using the new Duncan Multiple range test at $5 \%$ level of probability.

\section{RESULTS AND DISCUSSION}

\subsection{PHYSICAL AND CHEMICAL PROPERTIES OF SOIL}

The data on physical and chemical properties of soil of the experimental site is presented in Table 1 . The result showed that the soil $\mathrm{pH}$ was slightly acidic to moderately acidic before and after the experiment. The organic matter content was low throughout the experimental period. The chemical soil properties such as total nitrogen content, available phosphorus and exchangeable cations such as potassium, calcium and magnesium were very 
Table 1: Physical and chemical properties of soil of the experimental site before and after cropping in 2016 and 2017

\begin{tabular}{llllllllll}
\hline Year & Soil pH & $\begin{array}{l}\text { Org C } \\
(\%)\end{array}$ & $\begin{array}{l}\text { Org. Matter } \\
(\%)\end{array}$ & $\begin{array}{l}\text { Total N } \\
\mathrm{mg} \mathrm{g}^{-1}\end{array}$ & $\begin{array}{l}\mathrm{P} \\
\mathrm{mg} \mathrm{g}^{-1}\end{array}$ & $\begin{array}{l}\mathrm{K} \\
\mathrm{cmol} \mathrm{kg}^{-1}\end{array}$ & $\begin{array}{l}\mathrm{Ca} \\
\mathrm{cmol} \mathrm{kg}^{-1}\end{array}$ & $\begin{array}{l}\mathrm{Mg} \\
\mathrm{cmol} \mathrm{kg}^{-1}\end{array}$ & $\begin{array}{l}\mathrm{Zn} \\
\mathrm{mg} \mathrm{kg}^{-1}\end{array}$ \\
\hline $2016 \mathrm{a}$ & 6.1 & 0.82 & 1.41 & 0.07 & 6.67 & 0.31 & 5.05 & 0.28 & 0.56 \\
$2016 \mathrm{~b}$ & 5.9 & 0.54 & 0.93 & 0.04 & 5.42 & 0.32 & 4.39 & 0.21 & 0.54 \\
2017 & 5.8 & 0.50 & 0.86 & 0.03 & 3.28 & 0.30 & 4.23 & 0.19 & 0.53 \\
\hline
\end{tabular}

a Before initial cropping, b. End of first year cropping.

low; and available micronutrients such as zinc was very low before and at the end of the cropping seasons. These low soil nutrients of the study site are below the critical levels for optimum crop growth and yield using soil data rating as suggested by Linsday \& Norvell (1978); FDALR (1990) which is as follows; organic carbon, 1-1.4 \%, total nitrogen, 0.151-0.200 \%; available phosphorus, 7.0$20 \mathrm{mg} \mathrm{kg}^{-1}$; exchangeable potassium, $0.3-0.6 \mathrm{cmol} \mathrm{kg}^{-1}$; exchangeable calcium, $5-10 \mathrm{cmol} \mathrm{kg}^{-1}$; exchangeable magnesium $1-3 \mathrm{cmol} \mathrm{kg}^{-1}$ and available zinc $0.6-1.0 \mathrm{cmol} \mathrm{kg}^{-1}$. The low nutrient status of the experimental site, which is typical of Alfisols could be attributed to burning of crop residues, short fallow period and seasonal bush fire which deprives the soil of valuable organic matter. This is the reason why the cultivation of crops is done solely with the application of external inputs such as nitrogenous fertilizer which has led to the depletion of valuable micronutrients such as zinc over time. Eifediyi et al. (2016) had reported that soils of the study area are deficient in macro and micro nutrients which are essential for crop growth and development.

\subsection{METEOROLOGICAL DATA}

The rainfall data of the study site for 2016 and 2017 is presented in Figure 1. The data on rainfall indicated that no precipitation was experienced in the month of February during the two cropping seasons. But in 2016, September recorded the highest rainfall of $332 \mathrm{~mm}$ while the highest rainfall in 2017 was recorded in the month of August $(302.7 \mathrm{~mm})$. The rainfall in the study area has changed drastically in the past few decades and thus in sharp contrast to the rainfall pattern in the past which is bimodal in nature which starts in late march with the first peak in July, an August break and the second peak in September. This variation in rainfall could be attributed to the effect of climate change (Odjugo, 2011). The data on temperature is shown in Figure 2. The highest temperature in 2016 was experienced in the month of February while in 2017; the highest temperature was recorded in the month of March. The temperature of the study area has been on the increase in the past few years which can also be attributed to the effect of climate change (Ajibade, 2002).

The relative humidity is shown in Figure 3. The highest relative humidity was recorded in the month of September in 2016 while in 2017, it was in August.

\subsection{GROWTH PARAMETERS}

The effect of $\mathrm{Zn}$ and NPK fertilizer application rate

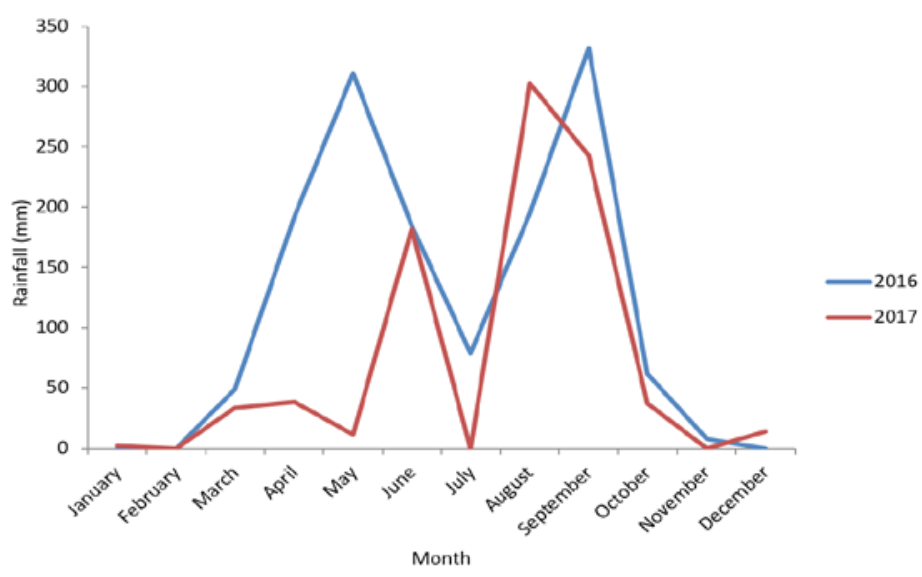

Figure 1: Rainfall pattern of the study area in 2016 and 2017. 


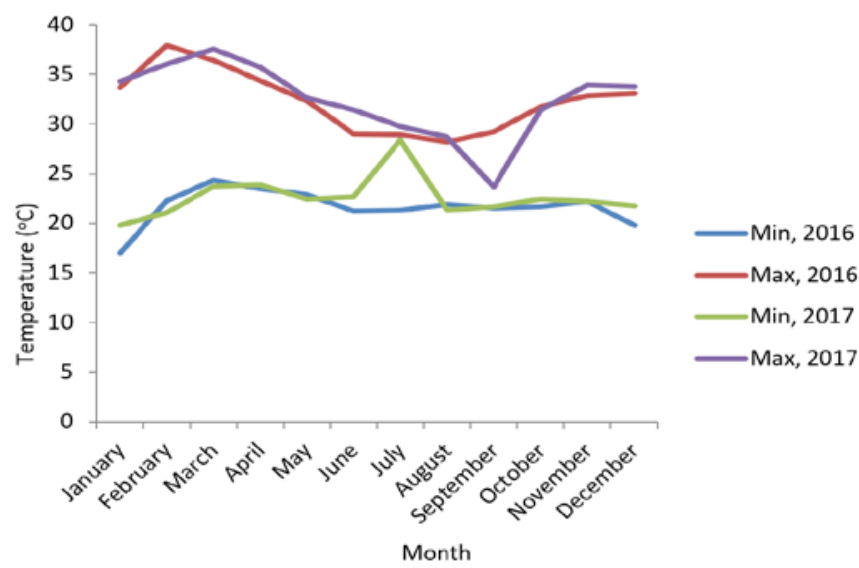

Figure 2: Temperature pattern of the study site in 2016 and 2017.

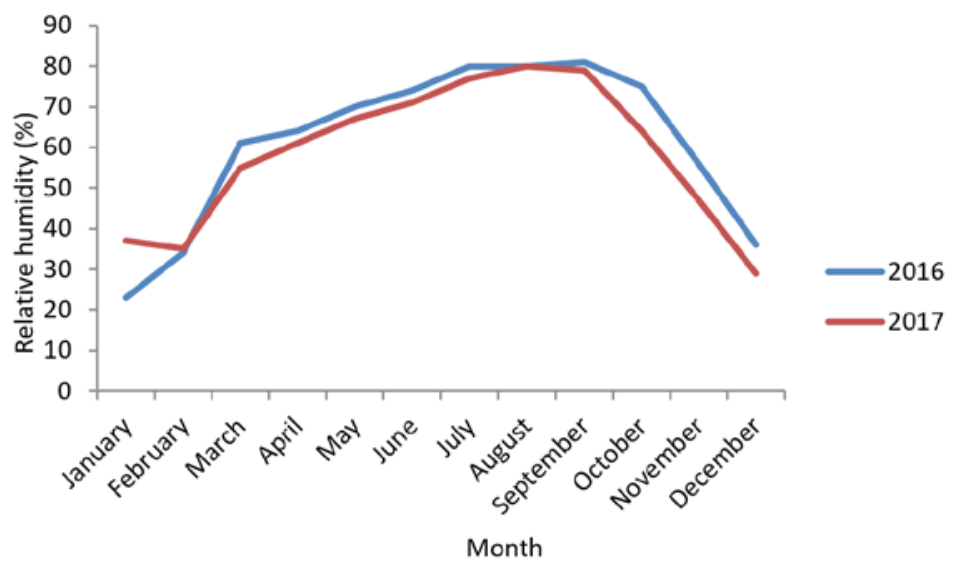

Figure 3: Relative humidity pattern of the study site in 2016 and 2017.

on the plant height and number of leaves of sesame at 4 , 6,8 and 10 weeks after sowing (WAS) are presented in Tables 2 and 3 . The data revealed that the zinc applied at the rate of $15 \mathrm{~kg} \mathrm{ha}^{-1}$ produced the highest plant height and number of leaves at the four sampling periods. There was no significant difference observed in the first season (2016) but in the second season (2017), significant differences $(p<0.05)$ were observed between the different rates. A trend was observed when the different rates of application of NPK 15:15:15 fertilizer was applied at the different sampling dates of 4, 6, 8 and 10 WAS with the $300 \mathrm{~kg} \mathrm{ha}^{-1}$ producing the tallest plants and the highest number of leaves. No significant difference was observed in the first year (2016), but in the second season (2017), significant differences $(p<0.05)$ were observed at the four sampling periods. The positive response of crop to the application of fertilizer most especially zinc in the increase in growth attributes could be attributed to the important role it plays in enzymatic reactions, regula- tion of auxin synthesis (Marschner,1995) metabolic processes, and oxidation-reduction reactions and for many enzymes which are needed for nitrogen metabolism (Hafeez et al., 2012; Omidian et al., 2012).

The effect of $\mathrm{Zn}$ and NPK fertilizer application rate on the leaf area index of sesame at 4, 6,8 and 10 weeks after sowing (WAS) is presented in Table 4 . The data revealed that the zinc applied at the rate of $15 \mathrm{~kg} \mathrm{ha}^{-1}$ produced the highest leaf area index at the four sampling periods, significant differences $(p<0.05)$ were observed between the different rates in the two seasons at 4 WAS. There was no significant difference observed in the first and second seasons at the 6,8 and 10 WAS. A similar trend was observed when NPK fertilizer was applied, with the $300 \mathrm{~kg} \mathrm{ha}^{-1}$ producing the highest leaf area index throughout the period of assessment in both seasons. Significant differences $(p<0.05)$ were observed between the different rates in the two seasons at 4 WAS. Increase in leaf area index with increase in rate of zinc fertilizer 
Table 2: Effects of $\mathrm{Zn}$ and NPK fertilizer on the plant height of sesame at 4, 6, 8 and 10 weeks after sowing

\begin{tabular}{|c|c|c|c|c|c|c|c|c|}
\hline \multirow[b]{3}{*}{ Treatments } & \multicolumn{2}{|c|}{4 WAS } & \multicolumn{2}{|l|}{6 WAS } & \multicolumn{2}{|l|}{8 WAS } & \multicolumn{2}{|c|}{ 10WAS } \\
\hline & \multicolumn{8}{|c|}{ Season } \\
\hline & 1 & 2 & 1 & 2 & 1 & 2 & 1 & 2 \\
\hline \multicolumn{9}{|l|}{$\mathrm{Zn}\left(\mathrm{kg} \mathrm{ha}^{-1}\right)$} \\
\hline 0 & 34.0 & 28.17 & 76.2 & 73.1 & 98.2 & 90.6 & 107.1 & 100.0 \\
\hline 5 & 39.4 & 30.75 & 81.4 & 75.2 & 102.0 & 93.3 & 110.9 & 102.8 \\
\hline 10 & 40.9 & 32.08 & 81.6 & 85.5 & 103.4 & 110.8 & 114.9 & 120.8 \\
\hline 15 & 46.8 & 34.67 & 87.4 & 80.2 & 108.3 & 102.3 & 117.6 & 114.4 \\
\hline Sed $(p<0.05)$ & ns & 0.740 & Ns & 5.21 & ns & 6.27 & ns & 5.19 \\
\hline \multicolumn{9}{|l|}{ NPK $\left(\mathrm{kg} \mathrm{ha}^{-1}\right)$} \\
\hline 0 & 29.9 & 18.25 & 69.3 & 50.8 & 86.3 & 69.3 & 96.7 & 80.8 \\
\hline 100 & 40.0 & 25.00 & 79.4 & 79.8 & 101.1 & 104.3 & 111.9 & 112.7 \\
\hline 200 & 40.4 & 36.50 & 84.2 & 87.4 & 107.9 & 109.6 & 116.7 & 117.5 \\
\hline 300 & 50.8 & 45.92 & 93.8 & 95.8 & 116.7 & 113.7 & 125.2 & 124.0 \\
\hline Sed $(p<0.05)$ & 6.48 & 0.938 & 8.56 & 6.28 & 7.68 & 6.40 & 7.01 & 6.15 \\
\hline Interaction & ns & 1.785 & Ns & 12.06 & ns & 12.73 & ns & 11.85 \\
\hline
\end{tabular}

Season 1 = data on 2016 cropping season; season 2 = data on 2017 cropping season

Table 3: Effects of $\mathrm{Zn}$ and NPK fertilizer on the number of leaves of sesame at 4, 6, 8 and 10 weeks after sowing

\begin{tabular}{|c|c|c|c|c|c|c|c|c|}
\hline \multirow[b]{3}{*}{ Treatments } & \multicolumn{2}{|l|}{4 WAS } & \multicolumn{2}{|l|}{6 WAS } & \multicolumn{2}{|c|}{8 WAS } & \multicolumn{2}{|c|}{ 10WAS } \\
\hline & \multicolumn{8}{|c|}{ Season } \\
\hline & 1 & 2 & 1 & 2 & 1 & 2 & 1 & 2 \\
\hline \multicolumn{9}{|l|}{$\mathrm{Zn}\left(\mathrm{kg} \mathrm{ha}^{-1}\right)$} \\
\hline 0 & 17.58 & 24.0 & 41.3 & 41.3 & 55.0 & 53.3 & 62.7 & 60.8 \\
\hline 5 & 18.92 & 24.0 & 41.4 & 41.4 & 57.7 & 58.1 & 66.7 & 64.5 \\
\hline 10 & 21.92 & 28.42 & 52.1 & 52.1 & 66.2 & 65.8 & 76.3 & 74.2 \\
\hline 15 & 22.83 & 30.42 & 57.1 & 57.1 & 68.8 & 78.1 & 77.6 & 75.6 \\
\hline Sed $(p<0.05)$ & ns & 1.28 & 3.63 & 3.63 & 3.77 & 3.13 & 3.89 & 3.89 \\
\hline \multicolumn{9}{|l|}{ NPK $\left(\mathrm{kg} \mathrm{ha}^{-1}\right)$} \\
\hline 0 & 12.42 & 13.00 & 28.1 & 28.1 & 45.1 & 49.3 & 54.9 & 53.1 \\
\hline 100 & 20.00 & 22.33 & 53.2 & 53.2 & 66.2 & 65.2 & 72.3 & 70.3 \\
\hline 200 & 20.25 & 30.33 & 54.1 & 54.1 & 64.0 & 68.2 & 74.6 & 72.2 \\
\hline 300 & 28.58 & 41.17 & 56.4 & 56.5 & 71.6 & 72.5 & 81.4 & 79.4 \\
\hline Sed $(p<0.05)$ & 2.11 & 1.28 & 3.63 & 3.63 & 3.77 & 3.13 & 3.89 & 3.89 \\
\hline Interaction & ns & 2.57 & Ns & 7.26 & 7.78 & 6.27 & ns & ns \\
\hline
\end{tabular}

Season 1 = data on 2016 cropping season; season 2 = data on 2017 cropping season

application may be due to the fact that zinc exerts a great influence in basic plant life processes, such as nitrogen metabolism, uptake of nitrogen and protein quality, photo synthase-chlorophyll synthesis, carbon anhydrase activity, resistance to abiotic and biotic stresses, protection against oxidative damage (Alloway, 2004; Potarzy- cki \& Grzebkisz., 2009; Tekale et al., 2009). The increase in the leaf area index as a result of zinc application is in agreement with the report of Badshah et al. (2013) who reported significant increase in leaf area with foliar application of zinc.

The effect of $\mathrm{Zn}$ and NPK fertilizer application 
Table 4: Effects of Zn and NPK fertilizer on the leaf area index of sesame at 4, 6, 8 and 10 weeks after sowing

\begin{tabular}{|c|c|c|c|c|c|c|c|c|}
\hline \multirow[b]{3}{*}{ Treatments } & \multicolumn{2}{|l|}{4 WAS } & \multicolumn{2}{|l|}{6 WAS } & \multicolumn{2}{|c|}{8 WAS } & \multicolumn{2}{|c|}{ 10WAS } \\
\hline & \multicolumn{8}{|c|}{ Season } \\
\hline & 1 & 2 & 1 & 2 & 1 & 2 & 1 & 2 \\
\hline \multicolumn{9}{|l|}{$\mathrm{Zn}\left(\mathrm{kg} \mathrm{ha}^{-1}\right)$} \\
\hline 0 & 2.75 & 2.64 & 3.75 & 3.64 & 4.47 & 4.58 & 4.62 & 4.73 \\
\hline 5 & 2.76 & 2.65 & 3.90 & 3.75 & 4.50 & 4.61 & 4.66 & 4.77 \\
\hline 10 & 2.94 & 2.83 & 3.98 & 3.86 & 4.52 & 4.63 & 4.70 & 4.81 \\
\hline 15 & 3.32 & 3.22 & 4.49 & 4.38 & 6.01 & 6.12 & 5.10 & 5.21 \\
\hline Sed $(p<0.05)$ & 0.386 & 0.386 & ns & ns & ns & ns & ns & ns \\
\hline \multicolumn{9}{|l|}{ NPK $\left(\mathrm{kg} \mathrm{ha}^{-1}\right)$} \\
\hline 0 & 2.17 & 2.06 & 3.59 & 3.86 & 4.71 & 4.82 & 4.51 & 4.62 \\
\hline 100 & 2.70 & 2.59 & 3.63 & 3.52 & 4.79 & 4.90 & 4.56 & $4 . .67$ \\
\hline 200 & 2.82 & 2.72 & 4.01 & 3.90 & 4.96 & 5.07 & 4.82 & 4.93 \\
\hline 300 & 4.08 & 3.97 & 4.88 & 4.77 & 5.05 & 5.16 & 5.19 & 5.30 \\
\hline Sed $(p<0.05)$ & 0.386 & 0.386 & ns & ns & ns & ns & ns & ns \\
\hline Interaction & 0.771 & 0.771 & ns & ns & ns & ns & ns & ns \\
\hline
\end{tabular}

Season 1 = data on 2016 cropping season; season 2 = data on 2017 cropping season

Table 5: Effects of Zn and NPK fertilizer on the dry matter accumulation (g) of sesame at 4, 6, 8 and 10 weeks after sowing in the 2016 and 2017 cropping seasons

\begin{tabular}{|c|c|c|c|c|c|c|c|c|}
\hline \multirow[b]{3}{*}{ Treatments } & \multicolumn{2}{|l|}{4 WAS } & \multicolumn{2}{|l|}{6 WAS } & \multicolumn{2}{|l|}{8 WAS } & \multicolumn{2}{|c|}{10 WAS } \\
\hline & \multicolumn{8}{|c|}{ Season } \\
\hline & 1 & 2 & 1 & 2 & 1 & 2 & 1 & 2 \\
\hline \multicolumn{9}{|l|}{$\mathrm{Zn}\left(\mathrm{kg} \mathrm{ha-}{ }^{1}\right)$} \\
\hline 0 & 0.56 & 0.58 & 1.61 & 1.60 & 2.04 & 1.79 & 2.62 & 2.50 \\
\hline 5 & 0.58 & 0.63 & 1.68 & 1.68 & 2.87 & 2.36 & 3.84 & 3.72 \\
\hline 10 & 0.71 & 0.68 & 2.04 & 1.89 & 2.61 & 2.62 & 3.91 & 3.79 \\
\hline 15 & 0.71 & 0.73 & 1.90 & 2.03 & 2.89 & 2.64 & 3.97 & 3.85 \\
\hline Sed $(p<0.05)$ & 0.060 & 0.014 & 0.187 & 0.187 & ns & ns & 0.355 & 0.355 \\
\hline \multicolumn{9}{|l|}{ NPK $\left(\mathrm{kg} \mathrm{ha-}-^{1}\right)$} \\
\hline 0 & 0.45 & 0.41 & 1.63 & 1.63 & 2.29 & 2.04 & 3.08 & 2.96 \\
\hline 100 & 0.58 & 0.56 & 1.69 & 1.69 & 2.65 & 2.40 & 3.42 & 3.30 \\
\hline 200 & 0.61 & 0.71 & 1.84 & 1.84 & 2.73 & 2.48 & 3.59 & 3.47 \\
\hline 300 & 0.91 & 0.95 & 2.05 & 2.05 & 2.75 & 2.50 & 4.25 & 4.13 \\
\hline Sed $(p<0.05)$ & 0.060 & 0.014 & 0.187 & 0.187 & 0.320 & 0.320 & 0.355 & 0.355 \\
\hline Interaction & 0.119 & 0.029 & 0.374 & 0.374 & ns & ns & 0.710 & 0.710 \\
\hline
\end{tabular}

Season 1 = data on 2016 cropping season; season 2 = data on 2017 cropping season

rate on the dry matter accumulation of sesame at 4, 6,8 and 10 weeks after sowing (WAS) is presented in Table 5. The data revealed that the zinc applied at the rate of $15 \mathrm{~kg} \mathrm{ha}^{-1}$ accumulated the highest mass at the four sampling periods. Significant differences $(p<0.05)$ were ob- served between the different rates at 4, 6 and 10 WAS, but there was no significant difference observed in the first and second seasons at the 8 WAS. A trend was observed when the different rates of application of NPK 15:15:15 fertilizer was applied at the different sampling dates of 4 , 
6,8 and 10 WAS with the $300 \mathrm{~kg} \mathrm{ha}^{-1}$ producing the highest dry matter mass. However, significant differences $(p<$ 0.05 ) were observed at the four sampling periods. There was also an increase in the dry matter accumulation and dry matter is an important parameter in the study of crop canopies. Increase in dry matter as the rate of application of $\mathrm{Zn}$ and NPK fertilizer increased could be attributed to the role performed by nitrogen and potassium in improving plant metabolism, enhancing plant meristematic activity and increasing the rate of photosynthesis (Alloway, 2004).

\subsection{YIELD AND YIELD COMPONENTS OF SESA- $\mathrm{ME}$}

The effects of zinc and NPK fertilizer on the yield components of sesame is presented in Table 6. The data showed that the zinc applied at the rate of $15 \mathrm{~kg} \mathrm{ha}^{-1}$ produced the highest number of capsules per plant and length of capsules which were significantly $(p<0.05)$ different from the other rates in the two years of study $(2016$ and 2017). The application of $300 \mathrm{~kg} \mathrm{ha}^{-1}$ also produced the highest number of capsules and length of capsules in the two years of study which were significantly different $(p<0.05)$ from the other rates. There was also a significant zinc and NPK fertilizer interaction.

The data on the yield of net plot and yield per hectare showed a similar trend as what was observed in the num- ber of capsules per plant. The highest net yield of (452 g and $454 \mathrm{~g}$ ) and yield per hectare $(502.2 \mathrm{~kg}$ and $505.1 \mathrm{~kg}$ ) were produced by applying zinc at the rate of $15 \mathrm{~kg} \mathrm{ha}^{-1}$ which were significantly different from the other rates in 2016 and 2017 cropping seasons respectively. Similarly, the application of NPK fertilizer at $300 \mathrm{~kg} \mathrm{ha}^{-1}$ gave the highest yield (net plot, $555.5 \mathrm{~g}$ and $554.3 \mathrm{~g}$ in 2016 and 2017 respectively) while the yield per hectare $(617.1 \mathrm{~kg}$ and $615.8 \mathrm{~kg}$ in 2016 and 2017 cropping seasons respectively) which were significantly different from the other fertilizer rates. There was also a significant interaction between the zinc and NPK fertilizer application.

Increasing the rate of zinc from 5 to 10 and $15 \mathrm{~kg} \mathrm{ha}^{-1}$, significantly increased yield and yield components. This is in agreement with Cakmak, (2000) and Omidian et al. (2012) who reported that zinc application increased the yield components of sesame as a result of the role it plays in cell division, cell enlargement and synthesis of protein. Zinc also regulates the membrane function and provides resistance to environmental stress in crop plant. The foliar spray of $\mathrm{Zn}$ increased the number of capsules and number of seeds per capsule (Bakry et al., 2012). This may be due to the involvement of zinc in photosynthesis, chlorophyll production, pollen function and fertilization (Pandey et al., 2006). Saedi (2002) stated that the foliar application of zinc promoted the vegetative and flowering stages of crops due to increase in the plant metabolism and photosynthesis. This increase in sesame yield may also be due to the abundant efficacy of en-

Table 6: Effects of Zn and NPK fertilizer on the yield components of sesame in the 2016 and 2017 cropping seasons

\begin{tabular}{|c|c|c|c|c|c|c|c|c|c|c|}
\hline \multirow[b]{3}{*}{ Treatments } & \multicolumn{2}{|c|}{ Number of capsules } & \multicolumn{2}{|c|}{$\begin{array}{l}\text { Length of capsules } \\
(\mathrm{cm})\end{array}$} & \multicolumn{2}{|c|}{$\begin{array}{l}\text { Yield of net plot } \\
(\mathrm{g})\end{array}$} & \multicolumn{2}{|c|}{$\begin{array}{l}\text { Yield } \\
\left(\mathrm{kg} \mathrm{ha}^{-1}\right)\end{array}$} & \multicolumn{2}{|c|}{$\begin{array}{l}\text { Zinc concentration } \\
\left(\mathrm{mg} \mathrm{kg}^{-1}\right)\end{array}$} \\
\hline & \multicolumn{10}{|c|}{ Season } \\
\hline & 1 & 2 & 1 & 2 & 1 & 2 & 1 & 2 & 1 & 2 \\
\hline \multicolumn{11}{|l|}{$\mathrm{Zn}\left(\mathrm{kg} \mathrm{ha}^{-1}\right)$} \\
\hline 0 & 61 & 62 & 3.23 & 3.27 & 353.6 & 354.1 & 392.9 & 393.4 & 9.48 & 8.93 \\
\hline 5 & 62 & 64 & 3.44 & 3.33 & 378.2 & 380.4 & 420.2 & 422.6 & 14.20 & 16.53 \\
\hline 10 & 75 & 76 & 3.33 & 3.44 & 411.4 & 412.2 & 457.1 & 458.0 & 16.73 & 20.45 \\
\hline 15 & 100 & 101 & 3.41 & 3.52 & 452.0 & 454.6 & 502.2 & 505.1 & 20.55 & 21.95 \\
\hline Sed $(p<0.05)$ & 8.55 & 8.63 & 0.904 & 0.094 & 10.16 & 11.20 & 11.29 & 12.45 & 0.979 & 0.637 \\
\hline \multicolumn{11}{|l|}{ NPK $\left(\left(\mathrm{kg} \mathrm{ha}^{-1}\right)\right.$} \\
\hline 0 & 54 & 56 & 3.13 & 3.22 & 238.7 & 242.6 & 265.2 & 269.6 & 11.30 & 9.45 \\
\hline 100 & 74 & 74 & 3.35 & 3.38 & 368.2 & 370.0 & 409.1 & 411.1 & 16.33 & 17.59 \\
\hline 200 & 75 & 76 & 3.42 & 3.45 & 432.9 & 434.4 & 481.0 & 482.7 & 16.60 & 20.08 \\
\hline 300 & 95 & 96 & 3.50 & 3.50 & 555.4 & 554.3 & 617.1 & 615.8 & 17.75 & 20.78 \\
\hline s.e.d $(p<0.05)$ & 8.55 & 8.63 & 0.904 & 0.094 & 10.16 & 11.20 & 11.29 & 12.45 & 0.979 & 0.638 \\
\hline Interaction & 17.09 & 17.27 & 0.181 & 0.189 & 20.32 & 22.40 & 22.57 & 24.89 & 1.957 & 1.275 \\
\hline
\end{tabular}

Season 1 = data on 2016 cropping season; season 2 = data on 2017 cropping season 
zyme activities which influence plant pigments because zinc is an important component of all classes of enzymes (CIMMYT, 2006; Malakouti, 2007). Mohsen et al. (2009) also suggested that foliar spray of zinc increased the seed yield of safflower (Carthamus tinctorius L.). Similarly, foliar application of zinc sulfate significantly improved the seed yield of canola (Brassica napus L.) (Omidbeigi, 2005), safflower (Carthamus tinctorius L.) (Movahedy et al., 2009), lentil (Lens culinaris Medik.) (Nakhzari et al., 2011) and soybean (Glycine max (L.) Merr.) (Jamson et al., 2009).

Zinc concentration in sesame seed also increased as the rate of application of $\mathrm{Zn}$ and NPK fertilizer increased. This increase in the zinc concentration may be attributed to the fact that zinc has favorable effects on the metabolism of plant which might be responsible for greater metabolite accumulation in the reproductive organs (Babaeian et al.2011).

\section{CONCLUSION}

The study revealed that the application of zinc at $15 \mathrm{~kg} \mathrm{ha}^{-1}$ and NPK 15:15:15 at the rate of $300 \mathrm{~kg} \mathrm{ha}^{-1}$ improved the growth, yield attributes and zinc concentration of sesame seeds. The increase in the zinc content of sesame seeds will therefore help to alleviate zinc deficiency in human diet. Farmers should therefore be enlightened on the need for appropriate combination of zinc and NPK fertilizers combination for optimum zinc absorption in seeds in order to minimize deficiency in human diet.

\section{REFERENCES}

Aduloju, M.O. (2000). "Extractable micronutrients in the soils of Bolorunduro catena, Ilorin, Kwara State, Nigeria". Biosearch Research Communications, 12(2), 139-143.

Ajibade, L. T. (2002). Indigenous system of land evaluation in the Yoruba speaking areas of Kwara State. Unpublished PhD Thesis Obafemi Awolowo University, Ile Ife, Nigeria

Alloway. B.J. (2004). Zinc in soils and crop nutrition. Areas of the world with zinc deficiency problems. 2004.

Babaeian, M., Tavassoli, A., Ghanbari, A., Esmaeilian, Y., \& Fahimifard, M. (2011). Effects of foliar micronutrient application on osmotic adjustments, grain yield and yield components in sunflower ('Alstar') under water stress at three stages. African Journal of Agricultural Research, 6, 1204-1208

Badshah, N.L. \& Ayub, G. (2013). Effect of different concentrations of nitrogen and zinc on the growth of pecan nut seedlings. ARPN Journal of Agriculture and Biological Science, 8(4), 337- 343

Bakry, B.A., Tawfik, M.M., Mekki, B.B. \& Zeidan, M.S. (2012).
Yield and yield components of three flax cultivars (Linumusita tissimum L.) in response to foliar application with $\mathrm{Zn}, \mathrm{Mn}$ and Fe under newly reclaimed sandy soil conditions. American Euro-Asian Journal of Agriculture and Environmental Science, 12, 1075-1080.

Black, R.E., Victora, C, G., Walker, S.P., Bhutta, Z.A., Christian, P., de Onis, M., Ezzati, S., Grantham-McGregor, S. Katz, J., Martorell, R \&. Uauy, R. (2013). Maternal and child under nutrition and overweight in low-income and middleincome countries (and the Maternal and Child Nutrition Study Group). Lancet, 382(9890), 427-451. https://doi. org/10.1016/S0140-6736(13)60937-X

Borg, S., Brinch-Pedersen, H., Tauris, B. \& Holm, P.B. (2009). Iron transport, deposition and bioavailability in the wheat and barley grain. Plant and Soil, 325, 15-24. https://doi. org/10.1007/s11104-009-0046-6

Bouis, H.E., Hotz, C., McClafferty, B., Meenakshi, J. V. \&. Pfeiffer, W. H. (2011). "Biofortification: A new tool to reduce micronutrient malnutrition". Food and Nutrition Bulletin, 32, 31 - 40. https://doi.org/10.1177/15648265110321S105

Bouyoucos, G.J. (1962). Hydrometer method improved for making particle size analysis of soil. Agronomy Journal, 54, 564-565. https://doi.org/10.2134/agronj1962.00021962005 400050028x

Brady, N. \& Weil, R (1999). The Nature and Properties of Soils. Prentice Hall, Upper Saddle River.

Bray, R.H. \& Kurtz, L.T. (1945). Determination of total, organic and available forms of $\mathrm{P}$ in soils. Soil Science, 59, 39-45. https://doi.org/10.1097/00010694-194501000-00006

Cakmak, I. (2000). Possible role of zinc in protecting plant cells from damage by reactive oxygen species. New Phytology, 146, 185-202. https://doi.org/10.1046/j.1469-8137.2000.00630.x

Cakmak, I. (2008). Enrichment of cereal grains with zinc: Agronomic or genetic biofortification? Plant Soil, 302, 1-17. https://doi.org/10.1007/s11104-007-9466-3

Cakmak, I. (2014). Agronomic biofortification. Conference brief \#8, In: Proceedings of the 2nd Global Conference on Biofortification: Getting Nutritious Foods to People, Rwanda, 2014.

Carter, M.R. \& Gregorich, E. G. (2007). Soil Sampling and Methods of Analysis. CRC Press, 2nd Edn., Boca Roton, FL. pp: 427-444. https://doi.org/10.1201/9781420005271

Chowdhury, M. (2014). Address of ICN2 by Ms. Matia Chowdhury, Honorable Minister for Agriculture, Government of People's Republic of Bangladesh, November 2014, Rome, Italy. http://www.harvestplus.org/sites/default/files/Bangladesh\%20Statement\%20at\%20ICN2.pdf

CIMMYT (2006). World maize facts and trends. Meeting world maize needs: Technological opportunities and priorities for the public sector. Mexico. p. 60.

Eifediyi, E.K., Ahamefule, H.E Ojiekpon, I.F., Agbede, T.M Remison, S.U Aliyu, T.H., Olukayode, T.O.\& Bangura, A.K. (2016). Response of sesame (Sesamum indicum L.) to mulching and inorganic fertilizers application in a southern Guinea savannah zone of Nigeria. Journal of Agriculture and Forestry, 62, 201-216. https://doi.org/10.17707/ AgricultForest.62.2.18

FDALR, (1990). Soil Map of Nigeria. Federal Department of Agricultural Land Resources, Abuja.

Gee, W.G., \& Or, D. (2002). Particle-Size Analysis. p. 255-293. 
In: Dane, J., and G.C. Topp (eds.). Methods of Soil Analysis. Book Series: 5. Part 4. Soil Science Society of America. USA. https://doi.org/10.2136/sssabookser5.4.c12

Global Nutrition Report (GNR). (2014). Actions and Accountability to Accelerate the World's Progress on Nutrition. Washington, D.C.: International Food Policy Research Institute.

Graham R., Welch, R. \& Bouis, H. (2001). Addressing micronutrient malnutrition through the nutritional quality of staple foods: principles, perspectives and knowledge gaps. Advanced Agronomy, 70, 77-142. https://doi.org/10.1016/ S0065-2113(01)70004-1

Haas, J.D., Luna, S.V., Lung'aho, M.G., Wenger, M.J., MurrayKolb, L.E., Beebe, V., Gahatu, J.B. \&. Egli, I.M. (2016). Consuming iron biofortified beans increases iron status of Rwandan women after 128 days in a randomized controlled feeding trial. Journal of Nutrition, 146, 1586-1592. https:// doi.org/10.3945/jn.115.224741

Hotz C., \& McClafferty, B. (2007). From harvest to health: Challenges for developing biofortified staples and determining their impact on macronutrient status. Food Nutrition Bulletin, 28, 5271-5279. https://doi. org/10.1177/15648265070282S206

Hunt, N. \& Gilkes, R. (1992). "Farm Monitoring Handbook A practical down - to earth manual for farmers and other land users". University of Western Australia Ned lands, W.A. and Land management Society: Como, W.A.

Jamson, M., Galeshi, S., Pahlavani, M. H., \& Zeinali, E. (2009). Evaluation of zinc foliar application on yield components, seed yield and seed quality of two soybean cultivar in summer cultivation. Journal of Plant Production, 16(1), 17-28. (in Persian).

Kennedy, G., Nantel, G. \&. Shetty, P. (2003). The scourge of "hidden hunger": Global dimensions of micronutrient deficiencies. Food Nutrition and Agriculture, 32, 8-16.

Kuo, S. (1996). Phosphorus. In: D.L. Sparks, (ed.), Methods of soil analysis. Part 3 - Chemical methods. American Society of Agronomy, Madison, 869-919. https://doi.org/10.2136/ sssabookser5.3.c32

Linsday, W.L., \&. Norvell, W.A. (1978). Development of DTPA soil test for zinc, iron, manganese and copper. Soil Science Society of America Journal, 42, 421-428. https://doi. org/10.2136/sssaj1978.03615995004200030009x

Marschner, H. (1995). Mineral nutrition of higher plants $\left(2^{\text {nd }}\right.$ edition.). London: Academic Press.

Malakouti, M.J. (2007). Zinc is a neglected element in the life cycle of plants. Middle Eastern and Russian. Journal of Plant Science and Biotechnology, 1, 1-12.

Mclean, K. S., \& Langille, W. M. (1979). Studies in soil copper I: Factors affecting copper extractability. Communication in Soil Science and Plant Analysis. 7,771-785.

Minaleshewa A., Chandravanshi, B.S., \& Redi, M. (2010). Concentration levels of essential and non-essential metals in Ethiopian Khat (Catha edulis Forsk.). Biological Trace Elements Research, 138, 316-325. https://doi.org/10.1007/ s12011-010-8617-1

Minaleshewa A., Chandravanshi, B.S. \& Mesfin, R. (2010). Concentration levels of essential and non-essential metals in Ethiopian Khat (Catha edulis Forsk.). Biological Trace
Elements Research, 138, 316-325. https://doi.org/10.1007/ s12011-010-8617-1

Mohsen, M.D., Sayed, A.M.S. \& Ali, M. (2009). Foliar application of zinc and manganese improves seed yield and quality of safflower (Carthamus tinctorius L.) grown under water deficit stress. Industrial Crops and Products, 30, 82-92. https://doi.org/10.1016/j.indcrop.2009.02.004

Movahhedy-Dehnav, M., Modarres-Sanav, S. \& MokhtassiBidgoli, A. (2009). Foliar application of zinc and manganese improves seed yield and quality of safflower (Carthamus tinctorius L.) grown under water deficit stress. Indian Crops Production, 30(1), 22-31. https://doi.org/10.1016/j. indcrop.2009.02.004

Nakhzari, M.A., Tatari, M. \&. Arniaz, Q.A. (2011). The investigation of application times and amounts of zinc on yield and yield components of Lentil. Electronic Journal of Crop Production, 4(1), 17-29.

Nelson D.W. \&. Sommers, L.E. (1996). Total carbon, organic carbon and organic matter, In: Sparks D.L. (Ed.), Methods of Soil Analysis, part 3, 2nd ed. SSSA Book Series No. 5. ASA and SSSA, Madison, Wisconsin, pp. 961 - 1010. https://doi.org/10.2136/sssabookser5.3.c34

Odjugo, P. A. (2011). Climate change and global warming. The Nigeria Perspective. Journal of Sustainable Development and Environmental Protection, 1(1), 6-17.

Omidbeigi, R. (2005). Production and processing of medicinal plants. Razavy Ghods-Astan Press, Mashhad, Iran. 347p. (in Persian)

Omidian, A., Seyadat, S.A., Naseri, R. Moradi, X. (2012). Effects of zinc-sulfate foliar on yield, oil content and seed protein of four cultivars of canola. Iranian Journal of Agricultural Science, 14, 26-28.

Pandey, N., Pathak, G.C. \&. Sharma, C.P. (2006). Zinc is critically required for pollen function and fertilization in lentil. Journal of Trace Elements and Medical Biology, 20, 89-96. https://doi.org/10.1016/j.jtemb.2005.09.006

Pavlotska, L., Dudenko, N. \& Dimitrievich, L. (2007). Osnovi fiziologiyi, gigieni harchuvannya ta problem bezpekiharchovih produktiv. Sumy, Ukraine: Universitetska Kniga.Cited by Yudicheva O. (2014). Study of Zn content in biofortified tomatoes. The Advanced Science Journal, 7, 15-18. https:// doi.org/10.15550/ASJ.2014.07.015

Phattarakul, N., Rerkasem, B., Li, L.H., Wu, L.H., Zou, C.Q., Ram, H., Sohu, V.S. Kang, B.S. Surek,H., Kalayci, M.,Yazici, A., Zhang, F.S.\& Cakmak, I. (2012). Biofortification of rice grain with zinc through zinc fertilization in different countries. Plant Soil, 361, 131-141. https://doi.org/10.1007/ s11104-012-1211-x

Potarzycki, J. \& Grzebisz, W. (2009). Effect of zinc foliar application on grain yield of maize and its yielding components. Plant, Soil and Environment, 55(12), 519-527. https://doi. org/10.17221/95/2009-PSE

Prasad B.V.G., Smaranika, M., Rahaman, S. \& Prerna, B. (2015). Bio-fortification in horticulture crops. Journal of Agricultural Engineering and Food Technology, 2(2), 95-99.

Saedi, G.H. (2002). The investigation of seed yield genetic variation and other agronomy properties in linum genotypes with edible oil in Esfahan. Journal of Science and Technology of Agriculture and Natural Resources, 5, 107-109. 
Silva L. C., Santos, J.W., Dos, D.J. Vieira, D.J. Beltrão, N. E. De, M., Alves, I. \& .Jerônimo, J.F. (2002). Um método simple’s para se estimar área foliar de plantas de gergelim (Sesamum indicum L.). Revista Brasileira de Oleaginosas e Fibrosas, 6(1), 491-496.

Suresh, G., Murthy, I.Y.L.N., Sudhakara Babu, S. N. \&. Varaprasad, K. S. (2013). An overview of Zn use and its management in oilseed crops. Journal of SAT Agricultural Research, 11, 1-11. Publication of ICRISAT.

Tekale, R. P., Guhey, A., \& Agrawal, K. (2009). Impact of boron, zink and IAA on growth, dry matter accumulation and sink potential of pigeon pea (Cajanus cajan L.). Agricultural Science and Digestion, 29(4), 246-249.

Voortman, R. \& Bindraban, P.S. (2015). Beyond N and P: To- ward a land resource ecology perspective and impactful fertilizer interventions in sub-Saharan Africa. VFRC Report 2015/1. Virtual Fertilizer Research Center, Washington, DC.

Zubar, N. (2010). Osnovi fiziologiyi ta gigieni harchuvannya. Kyiv: Tsentr Uchbovoyi Literatury. Cited by Yudicheva O. (2014). Study of $\mathrm{Zn}$ content in biofortified tomatoes. The Advanced Science Journal, 7, 15 - 18. https://doi. org/10.15550/ASJ.2014.07.015

Zuo Y. \& Zhang, F. (2008). Effect of peanut mixed cropping with graminaceaous species on micronutrient concentrations and iron chlorosis of peanut plants grown in a calcareous soil. Journal of Plant and Soil, 306, 23-36. https://doi. org/10.1007/s11104-007-9484-1 